\title{
Cyber Bullying Among Law Student: How They Deal With It, Understand and Apply The Law
}

\author{
Antonius PS Wibowo ${ }^{1 *}$ \\ ${ }^{1}$ Faculty of Law, Atma Jaya Catholic University of Indonesia, Jakarta, Indonesia
}

\begin{abstract}
The phenomenon of cyber bullying may be a lot happening among students but the law is less functioned by them. It is interesting to research. The aim of this manuscript are to research cyberbullying among the law student, to know the level of understanding of the student about related law and the factors that affect students to apply the law. This research apply sampling survey method and respondent is sampel of Law Student of Atma Jaya Catholic University. Respondent answered mixed questioner (open question and closed question). Sampel of respondent is selected based upon purposive sampling. The results of this research are: most student does not have knowledge concerning existing law on Cyber Bullying and procedure to apply the law when cyber bullying occurs. The research find that factors that affect student to apply the law are knowledge and comprehension concerning the Law on Cyber Bullying, victim's own resource, and the damage experienced by the victim.
\end{abstract}

\section{Introduction and literature review}

In this paper there is a need to explain that the terminology and definition of cyber bullying known in the literature is not exactly the same as the terminology and definition known in criminal law. The consequence of it is that not all of cyber bullying known in the literature is a criminal according to criminal law.

\subsection{Definition and type of Cyber bullying}

The word Cyber bullying cannot be found in the Indonesian Dictionary in Networks (hereinafter written: KBBI Online). According to KBBI Online "cyber" means computer systems and information, cyberspace, related to the internet [1]; "bully" (English) is same as "menggertak" or "mengganggu" (Indonesian). Cyber bullying is "bully or disrupting in cyberspace done using a computer system and information related to the internet".

Cyber bullying is an extension of "bullying"; whereas "bullying" is physical or mental violence carried out by a person or group of people against someone or another group of people so that the victim feels persecuted [2]. Cyber bullying is "willful and repeated harm

\footnotetext{
* Corresponding author: antonius.wibowo@atmajaya.ac.id
} 
inflicted through the use of computers, cell phones, and other electronic devices"[3]. The element of cyber bullying covers: willful; repeated; harm; computers, cell phones, and other electronic devices [3].

Cyber bullying takes place in cyberspace, through communication methods such as email, text message, blogs, and personal Web sites [4]. Online games, especially massively multiplayer online role-playing games (MMORPGs), are another place where bullying occurs [4]. Social networking sites are some of the most common cyber bullying venues [4].

Cyber bullying in Indonesia is included in the definition of defamation or humiliation; this is actually inadequate, because the forms of Cyber bullying are wider than just defamation or insult [5]. Cyber bullying is a crime that is an extension of "bullying" which has been conventionally occurring; Cyber bullying takes the form of verbal abuse in cyberspace and the majority of children are victims [6].

Nancy Willard stated that Cyberbullying is being cruel to others by sending or posting harmful material using the internet or a cell phone [7]. Cyber bullying happens as follows:

1. Flaming. Online "fights" using electronic messages with angry and vulgar language;

2. Harassment. Repeatedly sending offensive, rude, and insulting messages;

3. Cyberstalking. Repeatedly sending messages that include threats of harm or are highly intimidating;

4. Denigration. Sending or posting cruel gossip or rumors about a person to damage his or her reputation or friendships;

5. Impersonation. Breaking into someone's account, posing as that person and sending messages to make the person look bad, get that person in trouble or danger, or damage that person's reputation or friendships;

6. Outing and Trickery. Sharing someone's secrets or embarrassing information online;

7. Exclusion. Intentionally excluding someone from an online group [7].

According to the Indonesian Attorney General's Legal Information Center, as quoted by Antonius PS Wibowo, there are 7 (seven) types of cyber bullying practices, namely:

1. Doing a repeated Missed call;

2. Sending e-mail/SMS containing insults/threats;

3. Spreading unpleasant rumors through SMS, e-mail, comments on social Network;

4. Thief Online Identity;

5. Share personal images without permission;

6. Inviting personal information or videos without permission; and

7. Make a blog containing someone's ugliness [8].

It can be concluded that the terminology and definition of cyber bullying known in the literature is not exactly the same as the terminology and definition known in criminal law.

\subsection{Cyber bullying as criminal under the law}

The types of cyber bullying consists of flaming action, harassment, impersonation, outing (spreading other people's secrets), trickery, exclusion, and cyberstalking [6]. This statement is refer indirectly to Willard. The Law Number 11 of 2008 only regulates the act of threatening and humiliation, and the act of cyber bullying hasn't been clearly codified. So there is a necessary to arrange clearly about the rules of cyber bullying in Indonesia [6].

Cyber bullying can be categorized as cybercrime with the following characteristics: (1) non-violence; (2) involves a minimum of physical contact; (3) using equipment and technology; and (4) utilizing global telematics (telecommunications, media and informatics) networks [2]. 
Cyber bullying is criminal under the law in Indonesia [8]. It is based on, among other, the existing several court decisions relating to the application of Article 27 paragraph (3) of Law Number 11 of 2008 in conjunction with Law No. 19 of 2016 (hereinafter written: ITE Law) concerning cyber bullying (defamation, humiliation) [8].

Cyber Bullying in Indonesia is a traditional crime committed by computer aids or information technology that attacks someone's good name. It can be included in the offense of insult and /or defamation [9]. In USA, certain cyber bullying activities are already considered criminal under the law, including harassment, pornography, and threats [4]. As more cyber bullying cases are brought to national attention, people are calling for new legislation to police additional bullying behaviors [4].

Lesson learn from the USA is implications for School/university Policy [10]. This is, a need to doing an advocation in Indonesia's school/university for six primary elements of what would constitute an effective school/university policy [10]. They include the following:

1. Specific definitions of harassment, intimidation, and bullying (including the electronic variants);

2. Graduated consequences and remedial actions;

3. Procedures for reporting;

4. Procedures for investigating;

5. Language specifying that if a student's off -campus speech or behavior results in "substantial disruption of the learning environment," or infringes on the rights of other students, the student can be disciplined; and

6. Procedures for preventing cyberbullying [10].

\section{Objective of the study}

The aim of this study are to research cyberbullying among the law student. This study also inevitably gives attention to know the level of understanding of the student about related law and the factors that affect students to apply the law.

\section{Methodology}

This research apply sampling survey method and respondent is Law Student of Atma Jaya Catholic University. Respondent answered mixed questioner (open question and closed question) in class before doing an exam. Sampel is selected based upon purposive sampling.

\section{Discussion}

\subsection{Many Kinds of cyberbullying occur}

Survey questions that reveal this problem are questions number 5 and 6 . Through this question, respondents are asked to answer about kind of cyber bullying they have experienced. The answer from respondent is as follows: 29 students have been hit by Cyber bullying. Kinds of cyber bullying occured are: hit by gossip or rumors, threats of violence and felt frightened, ostracized from relationships in cyberspace, repeated missed calls, personal images shared without permission, defamation, humiliation, and intimidation.

This survey do not explore relationship between the bullies and the victim. There are actually three theoretical frameworks that can be considered for understanding this issue, that is, relational aggression, cognitive-affective deficits, and power and control [11]. This survey 
do not also explore whether the respondent has committed cyber bullying to others. Thus, it is just focus on victim of cyber bullying and do not focus on bullies.

In education context, university/school is obliged to prevent students to do bullying, while simultaneously handling victims of bullying. In a broader sense university has a responsible to engaged his self to advancing responsible adolescent development, because responsible adolescent development - one that is healthy, fulfilling, engaged, and respectful of one's self and others - requires responsive relationships with families, peers, neighbors, schools, community organizations, religious institutions, and other socializing systems [12].

Prevention students to do bullying and urgently action of handling victims of bullying is regulated in Article 54 Paragraph (1) of Law No. 35 of 2014 (hereinafter written: Law No. 35/2014) and regulation of the Minister of Education and Culture No. 82 of 2015 concerning Prevention and Mitigation of Violence in school. There are actually a need to make regulation that prevent college students to do violence in the university.

In cyber bullying context, the most important preventive step that schools can take is to educate the school community about responsible use of their devices at all times (ideally through a concerted focus on digital citizenship re-sponsibilities) [13]. Students need to know that all forms of bullying are wrong and that those who engage in harassing or threatening behaviors will be subject to discipline [13].

Indonesia Child Protection Commission (hereinafter written: KPAI) has recorded data on students as perpetrators and victims of violence in school as follows: 127 students were victims, while 64 students were perpetrator; 71 students were victim of brawl, while 88 students were perpetrator [14]. Violence and bullying (includes cyber bullying) are ranked third of the case reported to KPAI in the last 5 years [15].

According to Reuters/Ipsos's research, $25 \%$ of child/adolescent from 18.000 sampling of adults in 24 countries (includes Indonesia) have been a victim of oppression on the internet [16]. Also, $91 \%$ of sampling of Indonesian people have faced a cyber bullying practices. Karen Gottfried (researcher of Ipsos) stated that cyber bullying has become a serious problem and somes victims did a suicide (includes in Indonesia) [16].

\subsection{Understandings level of the student about related law}

There are three questions in the survey questionnaire to reveal the level of students' understanding of the laws relating to cyber bullying, namely questions number 3, 10, and 11. Question number 3 is about the rules that could apply to cyber bullying case. Questions number 10 and 11 are about cyber bullying associated with types of complaint in a crime, namely complaint offenses/crime with accusation (delik aduan) and ordinary offenses/crime without accusation (delik biasa/laporan). Types of offenses in the National Criminal Code (hereinafter written: KUHP) can be divided into complaint offenses and ordinary offenses [17]. In ordinary offense, criminal cases can be processed without the consent or complaint from the victim, for example murder (Article $338 \mathrm{KUHP}$ ); while the complaint offence can not be processed without victim's complaint, such as adultery (Article 284 KUHP), defamation (Article 310 KUHP) [17].

The meaning of data of respondent's answer can be elaborated as follows. Firstly, mostly students from the class of 2013, 2014, 2015, and 2016 provided correct answer to question number 3 (118 from 149); however, mostly students from them provided wrong answer to question number 10 and 11 (108 from 149). This figure indicates that most students have "weak knowledge" and "no comprehension" about all of the question. This indication is in accordance with the respondent's answer to question number 9 concerning procedures for reporting cyber bullying to law enforcement officers. Respondents' answers to question number 9 are generally wrong. Based on this, it can be concluded that students also have weak knowledge about criminal procedural law related to cyber bullying. 
According to Bloom's Taxonomy of Educational Objectives, the lowest level of cognitive domain is "knowledge", above the lowest is "comprehension", while highest level is "evaluation" [18]. "Knowledge" is the recall of specific items, while "comprehension" is can recall, but can do a little more (e.g. paraphrase, define, discuss to some extent [18]. This theory has revise by Anderson and Krathwohl in 2001 [19]. Acoording to them, the cognitive dimension covers remember, understand, apply, analyse, evaluate, and create [19].

Secondly, weak knowledge and understanding of students about the law on cyber bullying may be caused by ITE Law uses long or complex sentences in formulating articles and criminal legal norms therein. The use of long or complex sentences can make students face a trouble to understand the articles and criminal legal norms therein. In this context it is relevant to remember the lex certa principle or bestimmtheitsgebot in criminal law [17]. This principle means that the law needs to be formulated in detail and carefully, and formulation of criminal provisions that are unclear or complicated will only raise legal uncertainty [17].

\subsection{Factors that affect student to apply the law}

There were four questions in the survey questionnaire to reveal the factors that affect student to apply the law, namely questions number 5, 6,8 and 9. Questions number 5 and 6 are about the type of cyber bullying experienced by respondents. While the questions number 8 and 9 are about respondent's response to cyber bullying that they experience.

The meaning of data of respondent's answer is as follows. Firstly, mostly victim ( 23 from 29 students) do not report to law enforcement officials about cyber bullying they experienced. Their reasons are do not understand how to report the incident to law enforcement officials. Other reason is the type of cyber bullying occurred is perceived by victims as a violation that can be tolerated. For examples, rumor and ostracized from group relations (exclusion).

Some of students who do not report to the law enforcement officials regarding cyber bullying occurred have actually take defend action as follows. They stop himself from responding to perpetrator. Therese Harasymiw stated in this regard that a user should not respond to a threatening message [4]. Often cyberbullies want a response, and a reply written in a moment of anger may be turned against the user [4]. The bully can claim that the victim initiated the fight and use the angry reactions as evidence [4].

Secondly, few victim of cyber bullying (6 from 29 students ) made a report to law enforcement officials about cyber bullying they experienced. Their reason is that they understand on how to report the incident to law enforcement officials. Also, the type of cyber bullying occurred is perceived by victims as violations that cannot be tolerated. For examples, defamation, humiliation, and intimidation. Lastly, the victims of cyber bullying have resources to report the incident, namely relationships with lawyers and police.

In America, attorney can act as representatives of victims of cyber bullying. In this case the attorney can issue an order to end dangerous messages and images [4]. He or she can also provide information about whether the cyberbullying would be grounds for a potential lawsuit for financial compensation [4]. In Indonesia, financial compensation (namely Restitution) for victims of cyber bullying is possible if Article 7 A of Law Number 31 of 2014 in conjunction with Law Number 13 of 2006 (hereinafter written: Law on Protection of Witnesses and Victims) be supplemented by LPSK Decree stating that victim of Cyber bullying are entitled to Restitution, as stipulated in Article 7A Paragraph (2) of the Law above mentioned. LPSK is Lembaga Perlindungan Saksi dan Korban (National Agency for Victim and Witness Protection). 


\section{Conclusion}

There are not much cyber bullying occured among Law Faculty students. The number of cyber bullying occured is less than $20 \%$ of the number of respondents. Students who do not reporting to law enforcement officers about cyber bullying occurred are more than the students do report to law enforcement officers. The reasons for do not reporting cyber bullying occurred are weak of knowledge about how to make reporting and the cyber bullying occurred can still be tolerated. The reasons for reporting cyber bullying occurred are: firstly, having knowledge about how to make reporting; secondly, the cyber bullying occured cannot be tolerated; thirdly, having resources that support smooth reporting. In general, students have a weak understanding about the criminal provisions in the ITE Law which regulates cyber bullying therein.

\section{References}

1. https://kbbi.kemdikbud.go.id/entri/siber

2. M. N. Muslihotin, Cyberbullying Sebagai Kejahatan Siber (cybercrime) dan Sanksi Hukumnya (Digital Library Universitas Islam Negeri Sunan Ampel, Surabaya, 2017) http://digilib.uinsby.ac.id/18974/5/Bab 3.pdf (accessed August 1st, 2018)

3. Cyberbullying Research Center, What is Cyberbullying? http://cyberbullying.org/what-is-cyberbullying (accessed April 7st, 2017)

4. T. Harasymiw, Cyberbullying And The Law: Digital and Information Literacy (The Rosen Publishing Group, Inc., New York, 2013)

5. A. Sanda, Tinjauan Yuridis Terhadap Fenomena Cyberbullying Sebagai Kejahatan di Dunia Cyber Dikaitkan Dengan Putusan Mahkamah Konstitusi Nomor 50/PUUVI/2008 (Skripsi) (Repocitory Universitas Hasanuddin, Makasar, 2016) http://repository.unhas.ac.id/bitstream/handle/123456789/20430/SKRIPSI LENGKAP-PIDANA-ANTONIUS SANDA.pdf (accessed August 1st, 2018)

6. I. A. D. Satyawati, S. P. M. E Purwani, KERTHA WICARA 3, 2, (2014)

7. N. Willard, M.S., J.D, An Educator's Guide to Cyberbullying and Cyberthreats (Center for Safe and Responsible Internet Use, Washington DC, 2005)

https://www.wcs.k12.va.us/users/honaker/cyberbullying-for-teachers.pdf (accessed August 2nd, 2018)

8. A. P. S. Wibowo, Analisa Peraturan Perundang-undangan tentang Hak Anak Korban Cyberbullying, dalam Prosiding Call Paper Pada Simposium dan Pelatihan Hukum Pidana dan Kriminologi Ke-IV (Genta Publishing, Lemlit Universitas Nusa Cendana Kupang dan MAHUPIKI, Yogyakarta, 2017)

9. D. A. Reppy, LEX PRIVATUM 4, 7, Pp. 61-68 (2016)

10. S. Hinduja, J. W. Patchin, Cyberbullying Legislation and Case Law: Implications for School Policy and Practice (Cyberbullying Fact Sheet) (Cyberbullying Research Center, Orlando U.S.A., created July 2008, updated January 2015) https://cyberbullying.org/cyberbullying-legal-issues.pdf (accessed August 11st, 2018)

11. C. Faucher, M. Jackson, W. Cassidy, Education Research International Vol. 2014, Article ID 698545 (Hindawi Publishing Corporation, Kairo, 2014) http://dx.doi.org/10.1155/2014/698545 (accessed August 11st, 2018)

12. Springer, Advancing Responsible Adolescent Development (Book Series: description) (Springer, Springer Nature Switzerland AG, 2007 - 2017) https://link.springer.com/bookseries/7284 (accessed August 11st, 2018)

13. S. Hinduja, \& J.W. Patchin, Cyberbullying Identification, Prevention, and Response (Cyberbullying Fact Sheet) (Cyberbullying Research Center, Orlando U.S.A., 2018) https://cyberbullying.org. (accessed August 11st, 2018) 
14. Susanto, Kekerasan Terhadap Anak di Sekolah Kian Marak (2016) http://sahabatkeluarga.kemdikbud.go.id/laman/index.php=tpost/xview\&id=1069 (accessed May 11st, 2017; 14:30 WIB)

15. D. Hendrian, Penambahan Jam Belajar Siswa, KPAI: Bisa Perbesar Kasus Bullying di Sekolah (June 14, 2017) http://www.kpai.go.id/berita/penambahan-jam-belajar-siswakpai-bisa-perbesar-kasus-bulleying-di-sekolah (accessed June 15, 2017; 13:20 WIB)

16. M. Firman, A. N. Ngazis, Cyberbullying, Ancaman Bagi Anak di Internet - Indonesia Belum Punya Aturan Komprehensif Soal Cyberbullying (Jan 12, 2012) http://fokus.news.viva.co.id/news/read/279625-cyberbullying-efek-samping-internetbagi-anak (accessed June 15, 2017; 14:15 WIB)

17. E. O. S. Hiariej, Prinsip Prinsip Hukum Pidana (Cahaya Atma Pustaka, Yogyakarta, 2014)

18. G. I. Tedi, Bloom's Taxonomy of Educational Objectives (Teaching and Educational Development Institute - University of Queensland, Australia, 1996) https://kaneb.nd.edu/assets/137952/bloom.pdf (accessed August 11st, 2018)

19. Anderson, Krathwohl, A Taxonomy for Learning, Teaching, and Assessing: A Revision of Bloom's Taxonomy of Educational Objectives (Longman, New York, 2001) https://citl.illinois.edu/docs/default-source/default-document-library/bloomstaxonomy-(revised).pdf. (accessed August 11st, 2018) 